\title{
Catharine Parr Traill: Three Bibliographical Questions
}

\author{
Rupert Schieder
}

The Centre for Editing Early Canadian Texts was established in 1979 to provide for contemporary readers reliable texts of classics of Canadian literature in English written in the eighteenth and nineteenth centuries. In my work for the Centre on Canadian Crusoes: A Tale of the Rice Lake Plains, finished by Catharine Parr Traill in I 850, I have come upon several bibliographical curiosities. I am not suggesting that they are unique. They are worth noting, I believe, because they illustrate different kinds of questions that occasionally confront researchers and editors.

The first was encountered during the attempt to establish the date of the first publication of Canadian Crusoes. Standard bibliographies of Canadian writing such as those by Morgan, Staton and Tremaine, and Stuart Wallace give the date as $1852 .{ }^{1}$ The first edition of R.E. Watters' A Check List of Canadian Literature, published in 1959, has the following entry:

the Canadian crusoes. A Tale of Rice Lake Plains, Ed. by Agnes Strickland. London, Hall, I852. 368p [Also: Toronto, McClelland, I923. 322p Other editions have title: LOST IN THE BACKwOODS. London, Nelson, I 882. Etc] [BM BVaU NSHD OTP QMM $]^{2}$

There are two errors here, in the form of the title and the name of the publisher. The definite article was used only in the title of the American edition, published in I853 (probably pirated), and subsequent impressions of that edition. The London publisher was not Hall, but Hall, Virtue. The date of the first publication is correct here.

The second edition of Watters, published in $\mathrm{I} 972,{ }^{3}$ repeats the entry from the first edition, with two changes. For the otp (Toronto Public Library) location, OLU (University of Western Ontario Library, London) is substituted. More important, the I852 date has been changed to I 850 . Having checked with the British Library and with the four Canadian locations

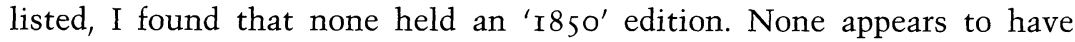
existed. How, then, can one account for the error?

It may simply be a printer's slip, not caught by the proofreaders who must 
have had an extremely difficult task. Perhaps one of Dr. Watters' team of researchers recorded the bibliographical details inaccurately from the book, if it was actually in front of him. Since most of the research depended on cards, there may have been an error on the card or the error may have been made during the transcribing of the card. There is one other possible source of error, illustrated by an entry in the National Union Catalogue Pre-1956 Imprints. This entry reads:

Traill, Catharine Parr (Strickland) I 802-I899. The Canadian Crusoes; a tale of the Rice lake plains, by Catharine Parr Traill, ed. by her sister, Agnes Strickland. Boston. Woolworth, Ainsworth [r 85o], 376 ocrw ${ }^{4}$

The composer of the file card reproduced in this entry appears to have supplied the I850 date in square brackets. He probably took his cue from Mrs. Traill's dedication dated 'I 5 th Oct. I 850,' the day she finished writing her story, which she then sent to her sister Agnes in England, to be published two years later. The Woolworth, Ainsworth impression of the novel is actually undated. However, from entries in the American Literary Gazette and Publishers' Circular, it can be established that this impression was issued some time between I 864 and I 870 when these partners operated in Boston. ${ }^{5}$ The source of this Woolworth, Ainsworth impression was the 1853 American edition. The error was probably introduced through the good intentions of a researcher who tried to be helpful by adding the date, I850, in square brackets. The [ 1850$]$ later became 1850 . Other errors in the bibliographies of Catharine Parr Traill can be accounted for by the failure to retain square brackets, with the result that a suggestion becomes a bibliographical 'fact.'

The questions raised by another non-existent edition or impression are answered with even less assurance. These arise from the listing of two extremely 'rare' copies that have their source in a much later edition. In I867 Thomas Nelson and Sons of Edinburgh bought the copyright of Canadian Crusoes from Mrs. Traill. ${ }^{6}$ Their edition of the book finally appeared in I882, with substantial changes, under the title Lost in the Backwoods: $A$ Tale of the Canadian Forest. Six later impressions of this edition, which can be distinguished only by the dates on their title pages and by the casings of the various Nelson's series in which they appeared, were published in I 884 , I 886, I890, I892, I896, and I90I. Having inspected copies of the I882 edition and these later impressions, I then turned to investigate an entry in The National Union Catalogue Pre-1956 Imprints:

Traill, Catharine Parr (Strickland) I 802-I 899. Lost in the backwoods. A tale of the Canadian forest. By Mrs. Traill ... London and New York, T. Nelson and sons, I 880 . NBUG NRU ${ }^{7}$ 
I wrote to both libraries indicated in the entry. The Rare Books Librarian of the University of Rochester (NRU) replied that the library did not hold a copy of this 'I 880' edition. The Grosvenor Reference Division of the Buffalo and Erie Public Library (NBuG) did have a copy. Unwilling to send the book by interlibrary loan, they supplied xeroxes of the casings and the first few pages. The casings, except for the colour, were similar to those of the 1882 edition and the I886 impression and different from those of the other five impressions, all of which belonged to various Nelson series. The pages inspected were exactly the same as those of the 1882 edition and the six subsequent impressions, with one prominent exception. The title page, otherwise the same, bore the date 'I 880 .' Strangely, the preface, like that of the I 882 edition and its impressions, was dated 'I882.' In addition, on the title page and on the upper casing and spine, Mrs. Traill is identified as the 'Author of "In the Forest", ' a version of the title of another of her works, Lady Mary and Her Nurse, that did not appear until I88I. So I turned my attention to the date on the title page. The ' $O$ ' of the ' 1880 ' seemed to be a little irregular, but the xerox copy did not provide a clear reproduction. I drove to Buffalo where I was able to see the copy in question. The ' $\mathrm{o}$ ' did indeed look quite irregular. An eraser applied by the Rare Book Librarian revealed that the ' $O$ ' had been tampered with; it appeared to have been, originally, a '6.' Later, by the use of an eight-powered type magnifier and other collational tools, members of the staff of The Centre for Editing Early Canadian Texts were able to identify this ' $1880^{\circ}$ ' copy as part of the I 886 impression. One can only speculate about the motives of the individual who altered this one digit, making this copy extremely 'rare.'

The bibliography of the works of Catharine Parr Traill presents another illustration of questionable motives, or perhaps one should say, ethics, this time on the part of a publisher. Whereas in the former example, one questionable copy was involved, here the legitimacy of a whole edition is open to question. This example presents the puzzling relation of three quite separate but obviously interrelated books, two by and one attributed to Catharine Parr Strickland.

In I 830 Harvey and Darton, the Quaker firm of 55 Gracechurch Street, London, published Sketches from Nature; or, Hints to Juvenile Naturalists. ${ }^{8}$ No author was named. Instead the writer was identified on the title page as 'The Author of the Young Emigrants - The Step-Brothers - Prejudice Reproved - Juvenile Forget Me Not - Nursery Fables, etc,' all works that can with confidence be attributed to the young Catharine Parr Strickland. It was the custom of the Strickland sisters, Elizabeth, Agnes, Jane Margaret, Catharine, and Susanna, to have their works issued anonymously, perhaps for the sake of genteel privacy. Unfortunately, this anonymity has led to several instances of confused attribution. 
Sketches from Nature comprises a four-page preface in which the writer states her aims and points out the benefits to be reaped by her audience; an eight-page autobiographical 'Introductory Address to my Young Readers'; two hundred and sixteen pages of text, divided into seven chapters of detailed descriptions of the characteristics and habits of domestic animals and birds, and a two-page 'Conclusion,' in which the writer repeats her aims. The book is marked by characteristics that appear consistently in all the works of Catharine Parr Strickland and Mrs. Traill published over seventyseven years: passages of autobiography, an insistence on the piety and morality that lead to responsibility and industry, precise details of natural history documented by footnotes and Latin terminology, and an emphasis on authenticity. This last is underlined by references to, quotations from, and paraphrases of such authorities as Buffon ${ }^{9}$ and Linnaeus, ${ }^{10}$ and to writers in the Encyclopaedia Britannica. Although she does not quote directly, she appears to have had access to the 1797 third edition of the Britannica, for the wording of her section on 'Columba, the Pigeon,' is closer to that edition than to the subsequent fourth (I8 Io), fifth (I 8 I9), and sixth (I823) editions. ${ }^{11}$ In her conclusion she speaks of the possibility of 'a future volume,' with 'The History of My Sister's Barbery Doves,' 'The Tortoise that lived in an old lady's garden in our village ...,' 'The Hedgehog, Peter, that lived in the potato-pit,' 'The History of my Dormice,' and 'a variety of other subjects. ${ }^{12}$ Copies of Sketches from Nature are rare. One is available in the British Library, one in the New York Public Library, and one in the Osborne Collection of the Toronto Public Library.

That same year Catharine worked on another book closely related to the Sketches. In a letter dated I3 November [I830] she wrote to James Bird ${ }^{13}$ about her success:

\footnotetext{
Allan Ransome told you that my friendly Quaker had accepted my Sketchbook of a Young Naturalist after having sadly disappointed me in the first instance by positively declining it. Perseverance thou art a virtue. I changed the old and rejected title, gave an old friend a new name, added a preface of a roguish description and offered it once more and was successful and to my utter amazement last Friday week I received the first set of proofs. ${ }^{14}$
}

The next year Harvey and Darton published her book with the title Sketch Book of a Young Naturalist; or, Hints to the Students of Nature. Once more the anonymous writer is identified by her published works. Two additions have been made to the list that had appeared on the title page of her I 830 work: a date for the Juvenile Forget-Me-Not, I 828, and of course, the title of Sketches from Nature. It is difficult to see just what Catharine meant when she described the six-page preface as 'roguish,' for she once more outlines 
her aims: truth, usefulness, and entertainment. The two hundred and twenty-four pages of text contain seven chapters, including the materials that she had listed at the conclusion of Sketches from Nature, on birds, insects, and animals. Again, to underline the authenticity of her work, she quotes from and paraphrases Buffon, ${ }_{1}^{15}$ Vitruvius, ${ }^{16}$ Pliny, ${ }_{1}^{17}$ and with some minor changes, several pages from one of the Letters from an American Farmer by Hector St. Jean de Crèvecoeur. ${ }^{18}$ In the two-page conclusion she expresses the hope that her readers will be led, by observing his works, to 'glorify their Maker. ${ }^{19}$ The Sketch Book, like its predecessor, is unmistakably the work of Catharine Parr Strickland. It too is rare. One copy is available in the British Library, one in the Traill Family Collection in the Public Archives of Canada, ${ }^{20}$ and one was added to the Osborne Collection in 1983 .

There is, in addition to the Sketches from Nature and the Sketch Book of a Young Naturalist, a third book, obviously derived in part from them, that presents the bibliographer with thorny problems of attribution and dating. Narratives of Nature, and History Book for Young Naturalists was published by Edward Lacey in London at $76 \mathrm{St}$. Paul's Churchyard. It too is rare. There is one copy in the British Library, one in the Osborne Collection, and one in the library of Carleton University, Ottawa. The title page provides neither the name of the author nor the date of publication. There are clues to both, however, in the publisher's claim that this new book is 'BY THE AUTHOR OF "Sketches from Nature," "The Young Emigrants," "Stepbrothers," "Prejudice Reproved," "Juvenile Forget-Me-Not," and "Nursery Fables".' Lacey obviously copied his title page from that of the Sketch Book, for the same titles of previous publications, with one minor omission, are listed in the same order. The entry in the catalogue of the British Library does not attribute this book to Catharine: after 'By the author of "Sketches from Nature" ' is added in square brackets, 'i.e. Agnes Strickland.' This attribution to Agnes is not surprising in view of the frequent confusion over the authorship of the books published anonymously by the five Strickland sisters. There is, however, no doubt that the six works listed are Catharine's, all published by 1830 . This list is important, because it may also provide a clue to the dating of Narratives of Nature.

What is not included in this list is the book by which Catharine Parr Traill, as she became in $1832,{ }^{21}$ was best known: The Backwoods of Canada published by Charles Knight in London in I 836, four years after Mrs. Traill had emigrated to Upper Canada. It might be expected that if Narratives of Nature were published after that date the title would be included in the list as an additional recommendation to prospective buyers of this new work. Thus, it might be assumed that Lacey published the book some time between I83I and I836. That, however, remains an assumption. Lacey might have had his own reasons for omitting the title of the later book. The 
latest possible date of publication can be established by the handwritten note at the top of the title page of the copy in the Osborne Collection: 'Frances Henslon [?] Jan y 1845.' The entry in the catalogue of the British Library included in square brackets 'I 845 ?.' All that can be determined is that the book was published some time between I 83 I, the date of the Sketch Book, and I 845 .

Although the attribution of the whole of Narratives of Nature to Catharine Parr Traill is questionable, it is obvious from the first page that it is directly related to her Sketches from Nature and Sketch Book of a Young Naturalist. The preface of Narratives illustrates what might be called the 'cut and paste' techniques employed by Lacey throughout the work. He printed the first five paragraphs of the preface of the Sketch Book, omitting the last paragraph, then printed the five paragraphs of the preface of the Sketches. It is not inconceivable that the final paragraph of the Sketch Book was omitted for the sake of economy, for if it had been included the new preface would have had to be continued on an additional page. The cut saved a leaf. The whole of the paragraph omitted is not wasted, however. The title page of Narratives includes two quotations. One 'The Lord is good to all, and his tender mercies are over all, ${ }^{22}$ is copied from the title page of the Sketch Book. Below it stands a second quotation, 'Nothing lives, and thrives, and breathes in vain, ${ }^{23}$ salvaged from the omitted paragraph of the Sketch Book. So the 'new' preface results from an economical combination of approximately equal parts of its two predecessors. The following 'Introductory Address to my Young Readers' is transcribed directly from the Sketches. The last nine lines are omitted and replaced by fourteen lines taken, with two changes, from the conclusion of the Sketch Book. The last sentence of the latter is omitted for no evident reason, except perhaps, once more, to save a leaf.

Fourteen of the twenty chapters of Narratives of Nature also result from an economical combination of approximately equal portions of the Sketches and the Sketch Book. The seven chapters of the latter reappear, with some deletions, as chapters I, II, IV, V, VII, IX, and x of Narratives. All except two of the numerous poems included by Catharine in the Sketch Book, all her footnotes, almost all her Latin identifications of plants, insects, and animals, and some sentences, paragraphs, and whole pages are deleted. It is significant that the material is invariably cut from the ends of chapters. Once more the publisher seems to have deleted to save pages. One footnote has been added, not to illuminate a point in the book, but to draw attention to publications by Lacey. ${ }^{24}$ The seven chapters of the Sketches with similar cuts, one extending to four pages of material taken from the Encyclopaedia Britannica and again at the end of a chapter, follow as chapters XII, XIII, XIV, XVI, XVII, XIX, and Xx of the Narratives. 
In addition to these fourteen chapters taken from Catharine's two works, there are six interjected among them, III, VI, VIII, XI, XV, XVIII, that contain quite different material, certainly not from other works by Catharine. The subject matter of the Sketches and the Sketch Book is limited to the experiences of the young Strickland sisters with birds, domestic animals, and insects. It is autobiographical, with the first-person narrator speaking in terms of her own feelings and attitudes, taking every opportunity to emphasize the relation between different aspects of nature and their omnipotent, omnipresent Creator. The reader is always conscious of the individual voice of Catharine underlining her moral purpose. The subject matter of the six added chapters is wider, far beyond the experience of Catharine. They contain accounts of such unrelated topics as 'Rope Bridges,' 'The Great Bell of Moscow,' 'Water Spouts,' the 'Porcelain Tower of Nankin,' etc. The tone of these chapters contrasts sharply with those among which they have been inserted. They are impersonal and devoid of moral content. One chapter does begin with the sentence, 'My sister Jane was fond of reading, ${ }^{25}$ but this device appears to be an attempt, actually quite ineffectual, to link together two disparate subjects in one chapter: 'Pillars of Sand' and 'The Peaks of Derbyshire,' and to fit them into the pattern of the preceding and succeeding chapters from Catharine's two books. In a few other passages, 'I' and 'we' are used, ${ }^{26}$ but the speaker is obviously not Catharine. These chapters stand apart from the rest in another way: each contains a plate, tipped in, illustrating the subject matter. There is also a frontispiece-one of only two illustrations that bear the name of the illustrator or engraver ${ }^{27}$ which has no direct relation to anything in the book. It was introduced, probably, to make the book more attractive to possible buyers. The rest of the illustrations remain as anonymously presented as the six chapters to which they are attached. Lacey was evidently not concerned with identifying the sources of his materials. ${ }^{28}$ His reasons remain as obscure as his sources. What can be said with confidence is that these six chapters are not the work of Catharine. They bear no relation to the aims and the characteristics of the writing that she produced during her long life in Great Britain and North America. On the other hand, the fourteen chapters that make up the larger part of the book are related directly to the two works by Catharine published by Harvey and Darton.

One obvious question needs to be answered: What was the relation, if any, of Lacey to Catharine and to Harvey and Darton? Three possible answers can be considered. First, that Mrs. Traill, as she must have been by the time Narratives of Nature was published, dealt directly with Lacey, made the changes in her fourteen chapters, and added the chapters taken from unidentified sources. Second, that Harvey and Darton sold her two books to Lacey, who made the changes and additions. Third, that Lacey 
published the new work without consulting either Mrs. Traill or Harvey and Darton.

The first possibility can be ruled out by one of Mrs. Traill's letters and three lists of her publications that she made late in her life. In answer to an inquiry made early in I 897 by Emma Hubbard, a friend of the family, about republishing her early works, she wrote somewhat disjointedly:

I had indeed but a very vague remembrance of the Sketch-book of a Young Naturalist - The first of the series - was the 'Sketches from Nature' which and possibly the best of the two but probably were in the same style now out of fashion - I just wrote what I saw and felt and what was familiar to my natural love of simple subjects drawn from observation and nature - the same as occur to this day; - a love of the wild creatures - birds, animals and trees and flowers - All the Lord's work, not man's -....

These little books were both written and I think published between I 827 and I 830 - and there was no special word about copyright ... I think they gave me I2 Guineas for the Sketches of Nature \& a year after I6 Guineas for the Sketch Book -.... Now the little works proved very popular but I never had any bonus and never thought any thing more about the matter.... Well my dear friend I married and went to Canada in I 832 and that was the finale of my writings and dealings in England until I made another venture and Virtue \& Hall, took a lease of my two Canadian books 'Lady Mary \& her Nurse' - and the 'Canadian Crusoes' ... I have no copy of the Dartons books. If I were inclined to do so I could make one good book out of the two Sk[etch] books and I have several unused Sketches of animal life and other such matter in hand.... ${ }^{29}$

It is obvious that she was unaware of and had no part in the publication of Narratives of Nature, for she speaks of the 'series' of 'two,' and of the 'finale' of her 'writings and dealings' in England until her Canadian Crusoes, published in 1852, and her Lady Mary and Her Nurse, published in I856. It is ironic that she should mention the possibility of doing just what Lacey did, that is, combining the two early books and adding more material. There is one difference, however: Mrs. Traill suggests adding more of her own writing; Lacey took his additions from other sources. Later in the letter she added:

I will make a list of my English books but fear they are out of print and hardly to be traced at this date as they were written as far back as 1819-up to I 830 .

Mrs. Traill did make at least three separate lists. ${ }^{30}$ Although there are some discrepancies, which might be attributed to her failing memory, they are consistent in relation to the three books under discussion: she always 
includes both the Sketches and the Sketch Book; she never mentions Narratives of Nature. In any case, she could not have dealt directly with Lacey, as the two books were not her property; they belonged to Harvey and Darton. ${ }^{31}$ So the possibility of Mrs. Traill's involvement in the third book can be ruled out.

The second possibility, that Harvey and Darton sold the books to Lacey, must remain just that. I have not so far been able to locate any records of either publishing firm. ${ }^{32}$ They could have done business together, for their years of operation did overlap. Founded in I 8I9, Harvey and Darton operated until I 847 when the firm was dissolved. ${ }^{33}$ According to one source, Lacey 'flourished' at 76 St. Paul's Courtyard, from which Narratives of Nature was issued, from I 830 to I $840 .{ }^{34}$ Another source extends Lacey's period of operation by several years, from 1829 to $1848 .^{35}$ Unfortunately no printer is named in Narratives. The Sears family, who printed eleven of the sixteen books published by Lacey in the Osborne Collection, operated between I 826 and $\mathrm{I} 858,{ }^{36}$ so facts about the printer are of no additional assistance. Nor are the illustrations, which appear to have been lifted from one or more books or magazines produced earlier. At this point, neither the date of publication nor the circumstances under which Lacey obtained the material in the original fourteen chapters can be determined with any definiteness.

About the reputation and business practices of Lacey, however, there is one statement, made in I 857 by Samuel Griswold Goodrich, the original 'Peter Parley,' in his Recollections of a Lifetime. He speaks of the 'London counterfeiters,' among them 'the bookseller by the name of Lacey. ${ }^{37} \mathrm{He}$ goes on to describe Lacey's method of operation: 'He was what is called a Remainder Man - that is, he bought the unsold and unsaleable ends of editions, put them in gaudy bindings, and disposed of them.' Edward Marston, in his After Work: Fragments from the Workshop of an Old Publisher, also identifies Lacey with 'cheap remainders. ${ }^{38}$

Of the three possibilities outlined only the first can be rejected with certainty, that of any relation between Mrs. Traill and Lacey. Since no evidence has so far been located of negotiations between Harvey and Darton and Lacey, the second and third possibilities can neither be accepted nor rejected.

One puzzling fact remains in relation to Mrs. Traill's apparent ignorance of the existence of Narratives of Nature. Although she was far from London during the time when Lacey would have published the book that included her material, her sisters Elizabeth, Agnes, and Jane Margaret were there. It is surprising that Agnes, who as her 'agent,' looked after Catharine's interests and carried on her negotiations, did not hear of the book and report to her sister. $^{39}$ There is no mention of it in any of the surviving letters. However, 
many of the letters written during this period did not survive the fire that consumed the Traill's house in $1857 . .^{40}$

Of the three questions raised in this paper, only one has been answered with any assurance. That there was no I 850 edition of Canadian Crusoes is certain. Its original listing can be attributed to a quite human error. The question of the motives that led to the 'creation' of an 'I $880^{\circ}$ ' edition of Lost in the Backwoods has been left unanswered and is likely to remain unanswered. To the complicated questions raised by Lacey's use of Catharine Parr Strickland's material, an answer can be provided for at least one: Narratives of Nature should not have been published with a title page that, by implication, attributed the book to Catharine Parr Strickland. It should appear in bibliographies of the works of Catharine Parr Traill only with some clear indication of the mixed nature of its contents. There are as yet no answers to the questions of the dating of Narratives of Nature and of the legitimacy of Lacey's business methods. Perhaps future investigation will provide them.

NOTES

I Henry J. Morgan, Bibliotheca Canadensis: or, A Manual of Canadian Literature (Ottawa: G.E. Desbarats, I867); Frances M. Staton and Marie Tremaine, $A$ Bibliography of Canadiana (Toronto: The Public Library, I934); W. Stuart Wallace, The Encyclopaedia of Canada (Toronto: University Associates of Canada, 1937).

2 R. E. Watters, A Check List of Canadian Literature and Background Materials, 1628-1950 (Toronto: University of Toronto Press, I959), pp. 291-92. In this and all subsequent quotations I have retained the original spelling and punctuation.

3 R.E. Watters, A Checklist of Canadian Literature and Background Materials, 16281960 (Toronto: University of Toronto Press, I972), p. 407.

4 National Union Catalogue Pre-1956 Imprints (London: Mansell, I978), vol. 599, p. 5 ro.

5 American Literary Gazette and Publishers' Circular 3 (I5 September 1864): 300; I4 (I February i 870): I62.

6 Public Archives of Canada, Traill Family Collection, MG 29, D 8I, (henceforth PAC, TFC), additional material, sheet 53, ALs, Catharine Parr Traill to Edward Traill, 8 May I 867.

7 National Union Catalogue Pre-1956 Imprints, vol. 599, p. 5 I I.

8 Judith St. John, The Osborne Collection of Early Children's Books 1566-1910

(Toronto: Toronto Public Library, I 975), vol. I, p. 472.

9 She might have had access to one or more of the numerous works of George Louis Leclerc, Comte de Buffon (I707-88). She speaks of 'abridged works of Buffon' (Sketches from Nature, p. I92).

Io Carolus Linnaeus, Carl Von Linné (I 707-78), Swedish botanist, author of such works as Systema Naturae, 1735, and Genera Plantarum, 1737.

I I Sketches from Nature, pp. 69-7 I; Encyclopaedia Britannica, 3 d ed. (Edinburgh: A. Bell and C. Macfarquhar, I 797), vol. 3, pp. I67-69.

I2 Sketches from Nature, p. $26 \mathrm{I}$. 
I 3 James Bird of Yoxford was a Suffolk poet and a friend of the Strickland sisters. See Carl Ballstadt, 'Catharine Parr Traill (I 802-I 899),' Canadian Writers and Their Works, Fiction Series, vol. I, eds. Robert Lecker, Jack David, and Ellen Quigley (Toronto: ECW Press, 1983), p. I 5 I.

I4 Public Archives of Canada, Susanna Moodie Collection, The John Glyde Papers, microfilm, reel A-I I 82. Allen Ransome (I 806-75) was a Quaker from Ipswich Suffolk who was on friendly terms with the Strickland family. See Susanna Moodie: Letters of a Lifetime, eds. Carl Ballstadt, Elizabeth Hopkins, and Michael Peterman (Toronto: University of Toronto Press, I985), p. 49, note 2.

I 5 See note Io above.

I6 Vitruvius, Marcus Pollio (fl. 4 O B.c.), De architecture. See Encyclopaedia Britannica, (Chicago: Encyclopaedia Britannica Association, I929), vol. 23, p. 224. Although Catharine quotes five paragraphs, she does not appear to be quoting directly from Book IV of Vitruvius, where the relevant material is located. She may be quoting from some general article on Vitruvius.

I7 Pliny the Elder, Gaius Plinius Secundus (23-79 A.D.), author of Historia Natura. See Encyclopaedia Britannica, i4th ed., vol. I 8, p. 77.

I 8 Hector St. Jean de Crèvecoeur, Letters from an American Farmer (London: Dent, [I9I2]), pp. 30-32, quoted in Sketch Book, pp. 56-59.

I9 Sketch Book, p. 223.

20 PAC, TFC, vol. 6, pp. A8982-9220.

2 I PAC, TFC, vol. 6, p. 8872 .

22 Ps. $145: 9$. On page 224 of the Sketch Book the quotation reads: 'That the Lord is good to all men, and his tender mercies are over all his works.'

23 Identified by Catharine as by 'Miss Roscoe - Sonnet on the Deity,' Sketch Book, p. viii.

24 Narratives of Nature (London: Lacey, n.d.), p. I 29.

25 Ibid., p. 38.

26 Ibid., pp. 152, 2 I 2.

27 The frontispiece The Zoological Gardens is by George Shepherd, delineator (1770I 830 ) and by Fenner Sears \& Co., engravers. The engraver is identified by Basil Hunnisett in A Dictionary of British Steel Engravers (Leigh-on-Sea: F.L. Lewis, 1980) only by works produced between [1 825] and [1 846]. The Porcelain Tower of Nankin, opposite p. I06, is identified only by the engraver T.A. Barfield about whom I have been able to locate no information.

28 Two probable sources, the editions of the Encyclopaedia Britannica published between 1797 and 1823, the third, fourth, fifth, and sixth, and The Penny Magazine of the Society for the Diffusion of Useful Knowledge, vols. I-I4, published between I 832 and I 845 in London by Charles Knight, were investigated without success.

29 PAC, TFC, vol. 2, p. 2276, ALS, Catharine Parr Traill to Emma Hubbard [early i 897].

30 PAC, TFC, vol. 3, pp. 4065-70; vol. 6, pp. 8948-57; Metropolitan Toronto Library, Frances Stewart Papers, Notes on the publication of her books by Catharine Parr Traill.

3 I See notes I4 and 29 above.

32 Robin Myers, the Honorary Archivist of The Worshipful Company of Stationers and Newspaper Makers, writes that she has not been able to locate any records.

33 Judith St. John, The Osborne Collection of Early Children's Books 1566-1910 (Toronto: Toronto Public Library, I975), vol. I, p. 472. Harvey and Darton sold their copyrights in I 852 to Arthur Hall, Virtue \& Co. who published in that year Mrs. Traill's Canadian Crusoes and later her Lady Mary and Her Nurse. See F.J. Harvey 
Darton, Children's Books in England, 3d ed. (Cambridge: University Press, 1982). 34 St. John, Osborne Collection, vol. I, p. 482.

35 Philip Brown, London Publishers and Printers c. 1800-1870 (London: British Library, 1982), p. I09.

36 Ibid., p. 172.

37 Darton, Children's Books in England, p. 226.

38 Edward Marston, After Work: Fragments from the Workshop of an Old Publisher (London: William Heinemann, I904), p. 325.

39 Metropolitan Toronto Library, Frances Stewart Papers, Notes on the publication of her books by Catharine Parr Traill.

40 PAC, TFC, vol. 2, p. 2952.

Illustrations are courtesy of the Osborne Collection of Early Children's Books, Toronto Public Library. 


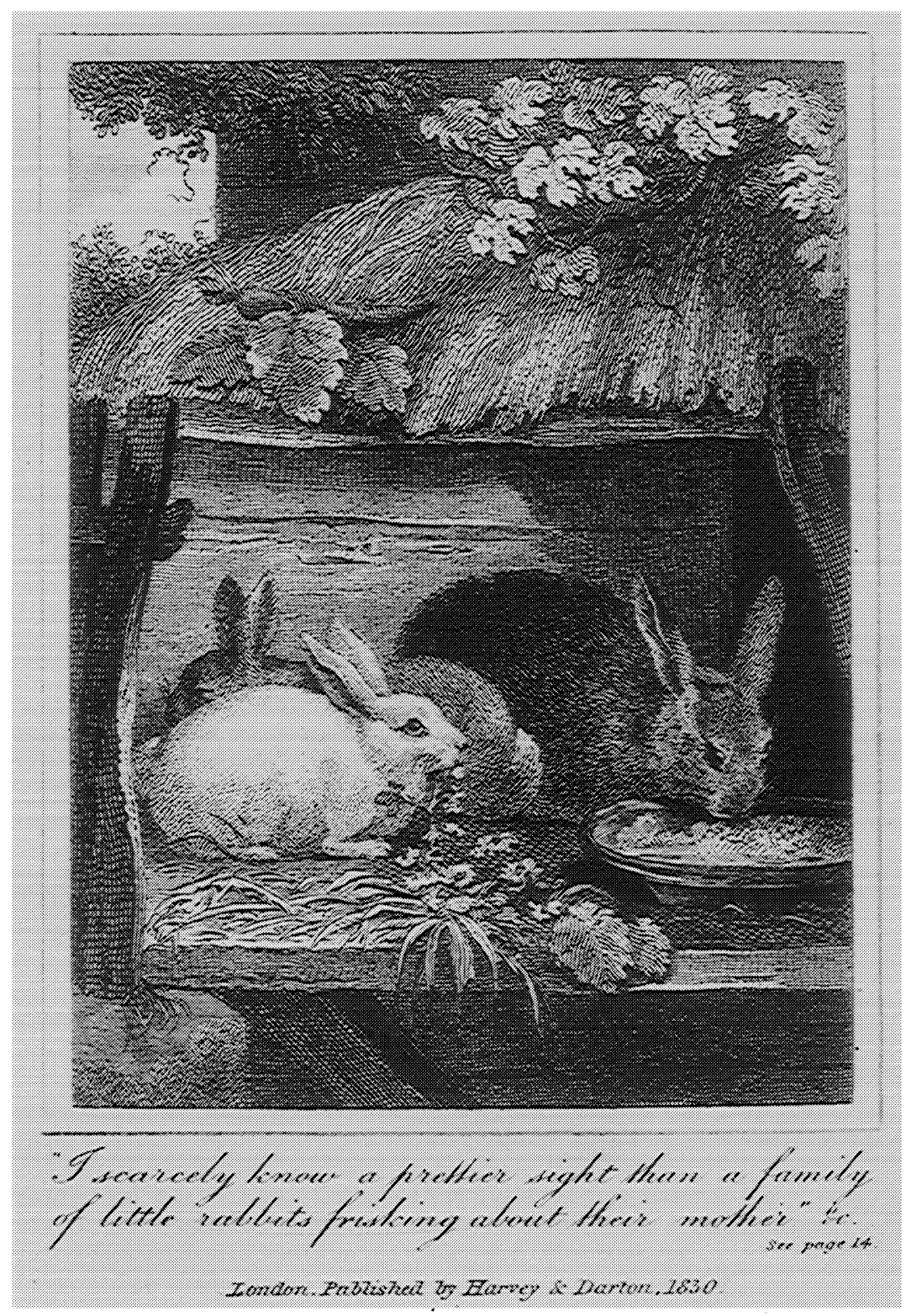

The frontispiece and title page of Sketches from Nature; or, Hints to Juvenile Naturalists which can confidently be attributed to Catharine Parr Strickland. 


\section{S K E T C H E}

rtsosing

\section{NAT U RE;}

$$
\text { or, }
$$

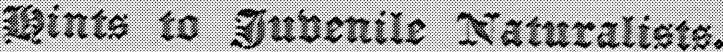

\section{RY TIz AUTHOR or}

ที丶

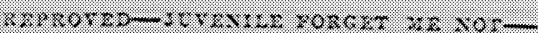

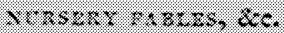

\section{LONDON :}

PRTNTED FOR IIATEY AND DARTON,

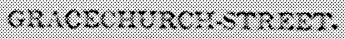




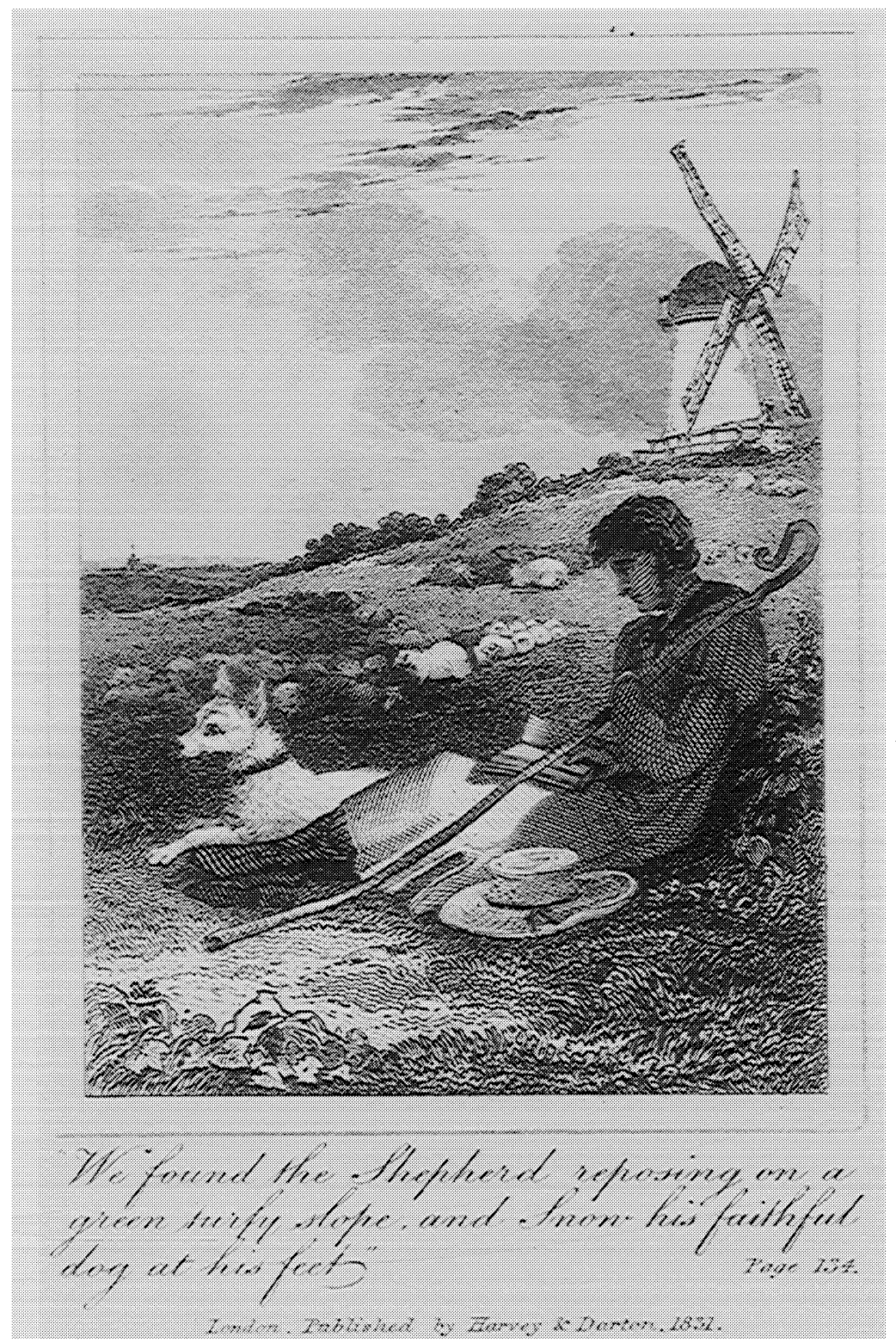

The frontispiece and title page of Sketch Book of a Young Naturalist; or, Hints to the Students of Nature also unmistakably the work of Catharine Parr Strickland. 


\section{SKETCH BOOK}

or

\section{A YOUNG NATURALIST; \\ $\mathbf{o r}$,}

FGints to the Students of Nrature.

24 mat Atran or

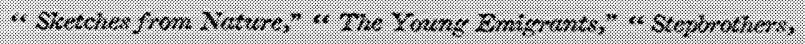

"Prejudice Rrmoned," "Jusenile Fonget-We-Not for 1828,"

cand "Nursery Fultes"

"The Lord is good to all, and kis tender mercles are over wil his works."

\section{IONDON :}

PRINTED FOR HARVEY AND DARTON, GRACRCHURCZ-STrRET.

wDccexxxi: 


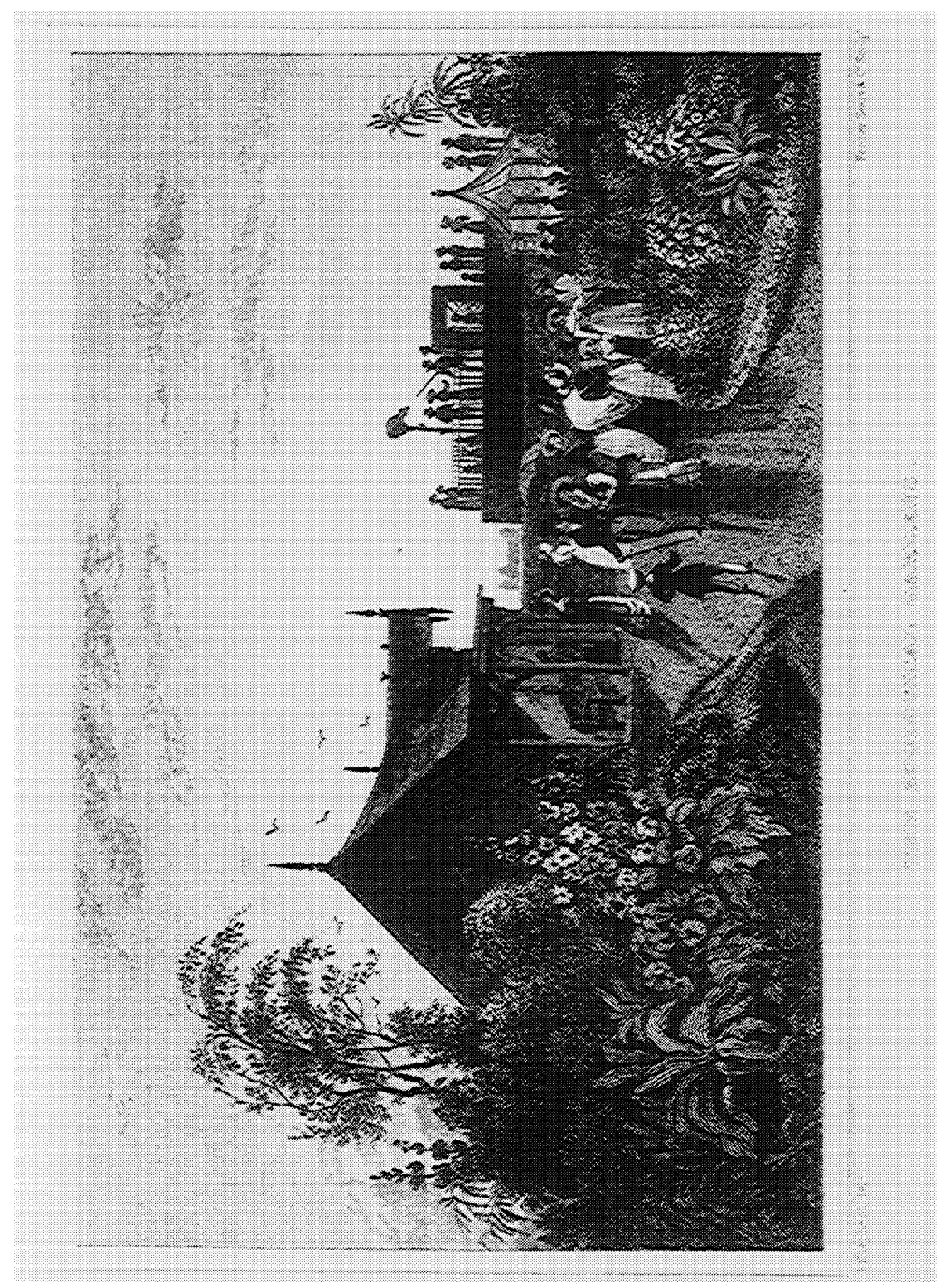

The frontispiece and title page of Narratives of Nature, and History Book for Young Naturalists implying that Catharine Parr Strickland is the author. 


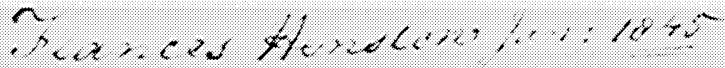 \\ NARRATIVES OF NATURE, $1 \times 2$}

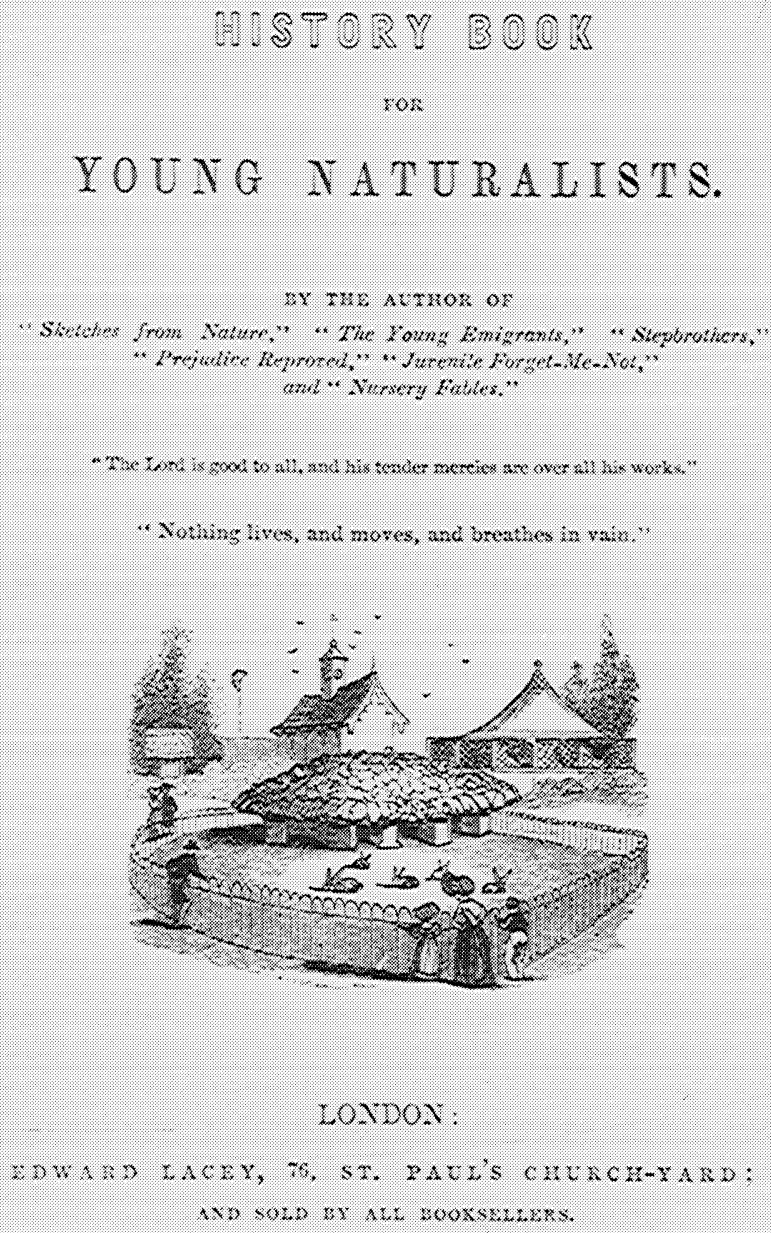

LOXDOX:

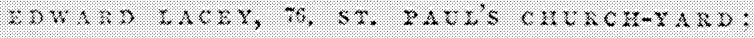

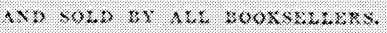

